\title{
RAMOWE STUDIUM UWARUNKOWAŃ I KIERUNKÓW ZAGOSPODAROWANIA PRZESTRZENNEGO ZWIĄZKU METROPOLITALNEGO A WKADZTWO PLANISTYCZNE GMINY
}

\section{WSTĘP}

Ustawą z 9 października 2015 r. o związkach metropolitalnych ${ }^{1}$ wprowadzono podstawy normatywne do tworzenia zrzeszeń jednostek samorządu terytorialnego położonych na obszarze metropolitalnym. Przepisami tej ustawy - przez wprowadzenie stosownych regulacji do ustawy z 27 marca 2003 r. o planowaniu i zagospodarowaniu przestrzennym ${ }^{2}$ - unormowano również zagadnienia planowania przestrzennego na obszarze metropolitalnym.

Mając na uwadze powyższe, wskazać należy, że w zamyśle twórców u.p.z.p. system aktów planowania przestrzennego miał być - podobnie jak w poprzednio obowiązujących regulacjach normatywnych, począwszy od dekretu z 2 kwietnia $1946 \mathrm{r}$. o planowym zagospodarowaniu przestrzennym kraju ${ }^{3}$ trójszczeblowy i obejmować planowanie centralne, regionalne oraz lokalne. Kształtowanie polityki przestrzennej oraz określanie przeznaczenia i zasad zagospodarowania terenów w sposób racjonalny, a także godzenie interesów grupowych z interesem jednostki, ponadlokalnych z lokalnymi wymaga bowiem - jak słusznie zauważa Marek Szewczyk - współdziałania wielu organów administracji publicznej działających na różnych szczeblach władzy ${ }^{4}$.

Rozwiązanie przyjęte przez polskiego ustawodawcę w 2003 r. zostało wyrażone w regulacji art. 3 u.p.z.p., zgodnie z którą kształtowanie i prowadzenie polityki przestrzennej państwa należy do zadań Rady Ministrów, kształtowanie i prowadzenie polityki przestrzennej w województwie należy do zadań samorządu województwa, a kształtowanie i prowadzenie polityki przestrzennej na terenie gminy - z wyjątkiem morskich wód wewnętrznych, morza terytorialnego i wyłącznej strefy ekonomicznej oraz terenów zamkniętych - stanowi zadanie własne gminy, przy czym uzupełnienie tej regulacji stanowi art. 4 ust. 1 i 2 u.p.z.p. wskazujacy tryby, w jakich następuje ustalenie przeznaczenia terenu, rozmieszczenie inwestycji celu publicznego oraz określenie sposobów zagospodarowania i warunków zabudowy. W nawiązaniu do powyższego

${ }^{1}$ Dz. U. 2015, poz. 1890 ze zm. (dalej jako: u.z.m.).

${ }^{2}$ Dz. U. 2017, poz. 1073 (dalej jako: u.p.z.p.).

${ }^{3}$ Dz. U. Nr 16, poz. 109.

${ }^{4}$ Tak M. Szewczyk, w: Z. Leoński, M. Szewczyk, M. Kruś, Prawo zagospodarowania przestrzeni, Warszawa 2012, s. 52. 
w pierwotnym tekście u.p.z.p. wprowadzono system aktów planowania przestrzennego składający się z koncepcji przestrzennego zagospodarowania kraju, programów zawierających zadania rządowe służące realizacji inwestycji celu publicznego o znaczeniu krajowym, planów zagospodarowania przestrzennego województwa, studiów uwarunkowań i kierunków zagospodarowania przestrzennego gminy oraz miejscowych planów zagospodarowania przestrzennego. W założeniu ustawodawcy system tych aktów powinien się charakteryzować wewnętrzną spójnościa, co wiąże się z ograniczeniem samodzielności podmiotów uczestniczących w procedurach planistycznych, w szczególności na szczeblu lokalnym ${ }^{5}$.

Przywołany art. 3 u.p.z.p. stanowiacy, że polityka przestrzenna ma być kształtowana i prowadzona na wskazanych powyżej trzech szczeblach sprawowania władzy publicznej ${ }^{6}$ - mimo kilkudziesięciu nowelizacji ustawy, które w znaczący sposób zmieniły brzmienie jej pierwotnego tekstu - obowiązywał w wersji przyjętej w pierwotnym tekście do 1 stycznia 2016 r., kiedy to zaczął obowiązywać dodany do niego ust. 2a. Zgodnie z jego regulacją kształtowanie i prowadzenie polityki przestrzennej na obszarze związku metropolitalnego (obszarze metropolitalnym) należy do zadań związku metropolitalnego, jeżeli został utworzony. Tym samym do organów administracji publicznej odpowiedzialnych za kształtowanie i prowadzenie polityki przestrzennej dołaczono organy związku metropolitalnego, a system aktów planowania przestrzennego - w związku z wprowadzeniem do niego ramowych studiów uwarunkowań i kierunków zagospodarowania przestrzennego związku metropolitalnego stał się czteroszczeblowy.

Wprawdzie przywołana u.z.m. pozostawała w obrocie prawnym zaledwie przez nieco ponad $\operatorname{rok}^{7}$, a na podstawie jej przepisów nie został utworzony żaden związek metropolitalny, ale ujęte w niej rozwiązania odnoszące się do planowania przestrzennego na obszarze metropolitalnym zostały powielone w ustawie regulujacej zasady i tryb tworzenia oraz zasady funkcjonowania związku metropolitalnego w województwie ślasskim, a także uwzględniane sa $\mathrm{w}$ toku prac legislacyjnych zmierzajacych do ustanowienia podstaw normatywnych tworzenia związków metropolitalnych poza województwem ślaskim ${ }^{8}$. Należy przy tym zauważyć, że dotychczas na obszarze Polski utworzony został

\footnotetext{
${ }^{5} \mathrm{~W}$ doktrynie przedmiotu podnosi się, że wewnętrznie spójny system aktów planowania przestrzennego jest jedną z podstawowych zasad wyrażonych w przepisach u.p.z.p. (zob. M. Szewczyk, w: Z. Leoński, M. Szewczyk, M. Kruś, op. cit., s. 52 i n.). Zob. też Z. Niewiadomski, Planowanie przestrzenne. Zarys systemu, Warszawa 2003, s. 41.

${ }^{6}$ Zupełnie inaczej ustawodawca określił bowiem - w art. 3 ust. 2 u.p.z.p. - rolę powiatu, wskazując, że do zadań samorządu powiatu należy prowadzenie, w granicach swojej właściwości rzeczowej, analiz i studiów z zakresu zagospodarowania przestrzennego, odnoszących się do obszaru powiatu i zagadnień jego rozwoju. Tak sformułowane zadanie wyklucza zaś tworzenie jakichkolwiek aktów planowania przestrzennego przez organy powiatu - zob.: M. Szewczyk, w: Z. Leoński, M. Szewczyk, M. Kruś, op. cit., s. 53; Z. Niewiadomski (red.) et al., Planowanie i zagospodarowanie przestrzenne. Komentarz, Warszawa 2011, s. 35.

${ }^{7}$ Została uchylona regulacja art. 62 ustawy z 9 marca 2017 r. o związku metropolitalnym w województwie śląskim, Dz. U. 2017, poz. 730 (dalej jako: u.z.m.w.ś.).

${ }^{8}$ Ujęto je w poselskim projekcie ustawy o Poznańskim Związku Metropolitalnym (druk nr 1196), który został odrzucony przez Sejm 9 marca 2017 r.
} 
- z dniem 1 lipca 2017 r. - jeden związek metropolitalny ${ }^{9} \mathrm{i}$ brak jakichkolwiek doświadczeń w zakresie wykonywania przez ten podmiot zadań publicznych ${ }^{10}$, także i w zakresie - wskazanego w art. 12 ust. 1 pkt 1 u.z.m.w.ś. - zadania sprowadzającego się do kształtowania ładu przestrzennego.

Mając zatem na uwadze powyższe, a także okoliczność, że z dniem 1 stycznia 2016 r. do polskiego porządku normatywnego wprowadzono nowa kategorię opracowania planistycznego, którym jest ramowe studium uwarunkowań i kierunków zagospodarowania przestrzennego związku metropolitalnego, konieczna wydaje się analiza charakteru normatywnego tego aktu, w szczególności uwzględniająca wpływ jego ustaleń na gminną politykę przestrzenna. Jak bowiem wskazano w uzasadnieniu projektu u.z.m., studium metropolitalne zawierać będzie - wiążące dla gmin wchodzących w skład związku metropolitalnego - wytyczne do tworzenia gminnych studiów uwarunkowań i kierunków zagospodarowania przestrzennego oraz gminnych planów zagospodarowania przestrzennego, przy czym jego uchwalenie nie będzie naruszać samodzielności planistycznej gmin, a jednocześnie umożliwi uchwalanie miejscowych planów zagospodarowania przestrzennego z uwzględnieniem potrzeb aglomeracji.

\section{WKADZTWO PLANISTYCZNE GMINY}

Analiza przepisów u.p.z.p., a zwłaszcza regulacja przywołanego powyżej art. 3 i art. 4 tej ustawy, prowadzi do wniosku, że ustawodawca przyją zasadę generalnej właściwości gminy w zakresie władczego określania przeznaczania terenu i warunków jego zabudowy. Oznacza to, że w aktualnym porządku normatywnym zasadą jest władztwo planistyczne gminy, inaczej zwane samodzielnościa planistyczna gminy ${ }^{11}$, od której to zasady ustawodawca wprowadza jednak wyjątki ${ }^{12}$.

${ }^{9}$ Zob. rozporządzenie Rady Ministrów z 26 czerwca 2017 r. w sprawie utworzenia w województwie śląskim związku metropolitalnego pod nazwą „Górnośląsko-Zagłębiowska Metropolia”, Dz. U. poz. 1290.

${ }^{10}$ Zgodnie z regulacją art. 12 ust. 1 u.z.m.w.ś., związek metropolitalny wykonuje zadania publiczne w zakresie: 1) kształtowania ładu przestrzennego; 2) rozwoju społecznego i gospodarczego obszaru związku metropolitalnego; 3) planowania, koordynacji, integracji oraz rozwoju publicznego transportu zbiorowego, w tym transportu drogowego, kolejowego oraz innego transportu szynowego, a także zrównoważonej mobilności miejskiej; 4) metropolitalnych przewozów pasażerskich; 5) współdziałania w ustalaniu przebiegu dróg krajowych i wojewódzkich na obszarze zwiazku metropolitalnego; 6) promocji zwiazku metropolitalnego i jego obszaru. Jak wskazano w ust. 2 tego artykułu, związek metropolitalny może realizować również zadania publiczne należące do zakresu działania gminy, powiatu lub samorządu województwa lub koordynować realizację tych zadań na podstawie porozumienia zawartego z jednostką samorządu terytorialnego lub ze związkiem jednostek samorządu terytorialnego, a zgodnie z treścią ust. 3 - może realizować także zadania publiczne należące do zakresu działania administracji rządowej na podstawie porozumienia zawartego $\mathrm{z}$ organem administracji rządowej.

${ }_{11}$ Tak Z. Niewiadomski (red.) et al., Planowanie..., s. 31.

${ }_{12}$ Zob. np. art. 51 ust. 1 pkt 3 u.p.z.p., zgodnie z którym decyzje o lokalizacji inwestycji celu publicznego na terenach zamkniętych wydaje wojewoda. Zob. także art. 60 ust. 3 u.p.z.p., zgodnie z którym wojewoda wydaje również decyzje o warunkach zabudowy na terenach zamkniętych. 
Władztwo to rozumiane jest jako ustawowe upoważnienie organów gminy do określania przeznaczania gruntów położonych na obszarze ich działania, a także określania sposobów ich zagospodarowania i warunków zabudowy, a sięga tak daleko, że od treści - stanowionego przez radę gminy - miejscowego planu zagospodarowania przestrzennego albo wydawanej przez wójta (burmistrza lub prezydenta miasta) decyzji o warunkach zabudowy i zagospodarowania terenu ustawodawca uzależnił sposób wykonywania prawa własności nieruchomości ${ }^{13}$. Jak bowiem wskazano w regulacji art. 6 ust. 2 pkt 1 u.p.z.p., każdy ma prawo do zagospodarowania terenu, do którego ma tytuł prawny, zgodnie $\mathrm{z}$ warunkami ustalonymi $\mathrm{w}$ miejscowym planie zagospodarowania przestrzennego albo decyzji o warunkach zabudowy i zagospodarowania terenu, jeżeli nie narusza to chronionego prawem interesu publicznego oraz osób trzecich.

Majac na uwadze powyższe, trzeba zauważyć, że - jak wskazano wprost w art. 3 ust. 1 pkt 1 u.p.z.p. - do zadań własnych gminy należy kształtowanie i prowadzenie polityki przestrzennej na jej terenie, $\mathrm{w}$ tym uchwalanie studium uwarunkowań i kierunków zagospodarowania przestrzennego gminy oraz miejscowych planów zagospodarowania przestrzennego. Zgodnie zaś $\mathrm{z}$ regulacja art. 4 ust. 1 u.p.z.p. ustalenie przeznaczenia terenu, rozmieszczenie inwestycji celu publicznego oraz określenie sposobów zagospodarowania i warunków zabudowy terenu następuje w miejscowym planie zagospodarowania przestrzennego. Skoro więc w studium gminnym określa się politykę przestrzenna gminy, w tym lokalne zasady zagospodarowania przestrzennego $^{14}$, a w planie miejscowym ustala się przeznaczenie terenów ${ }^{15}$, w doktrynie przedmiotu podnosi się, że niezbyt fortunne było zaliczenie przez ustawodawcę miejscowego planu zagospodarowania przestrzennego do działań opisanych jako prowadzenie polityki przestrzennej ${ }^{16}$.

Podkreślenia wymaga bowiem, że wskazane powyżej gminne akty planowania przestrzennego - co nie budzi żadnych wątpliwości ${ }^{17}$ - mają całkowicie odmienny charakter prawny. I choć z uwagi na wiążący, albo w stosunkach wewnątrz administracji publicznej, albo powszechnie, charakter ustaleń ujętych $\mathrm{w}$ tych aktach, zarówno studium uwarunkowań i kierunków zagospodarowania przestrzennego gminy oraz miejscowy plan zagospodarowania przestrzennego są aktami normatywnymi ${ }^{18}$, ale inna jest moc wiążąca tych aktów. Jak bowiem wskazano wprost w przepisach u.p.z.p., studium gmin-

${ }^{13}$ Por. M. Szewczyk, w: Z. Leoński, M. Szewczyk, M. Kruś, op. cit., s. 59.

14 Zob. art. 9 ust. 1 u.p.z.p. i komentarz do tego artykułu: Z. Niewiadomski (red.) et al., Planowanie..., s. 80 i n.

15 Zob. art. 14 ust. 1 u.p.z.p. i komentarz do tego artykułu: Z. Niewiadomski (red.) et al., Planowanie..., s. $141 \mathrm{i} \mathrm{n.}$

${ }^{16}$ Tak Z. Niewiadomski (red.) et al., Planowanie..., s. 34.

17 Por.: ibidem, s. 34; M. Szewczyk, w: Z. Leoński, M. Szewczyk, M. Kruś, op. cit., s. 90 i n.; A. Plucińska-Filipowicz, T. Filipowicz, w: M. Wierzbowski, A. Plucińska-Filipowicz (red.) et al., Ustawa o planowaniu i zagospodarowaniu przestrzennym. Komentarz, Warszawa 2016, s. 65.

18 Szerzej na temat charakteru normatywnego studium uwarunkowań i kierunków zagospodarowania przestrzennego gminy oraz miejscowego planu zagospodarowania przestrzennego zob. K. Małysa-Sulińska, Normy kształtujace ład przestrzenny, Warszawa 2008, s. 233-235 i 288-291. 
ne nie jest aktem prawa miejscowego ${ }^{19}$, a plan miejscowy jest aktem prawa miejscowego ${ }^{20}$. To zaś oznacza, że jedynym aktem planowania przestrzennego, który stanowi źródło prawa powszechnie obowiązującego na obszarze gminy, jest miejscowy plan zagospodarowania przestrzennego, a w związku z tym wyłącznie jego ustalenia stanowią podstawę prawną wydawania rozstrzygnięć zawartych w indywidualnych aktach administracyjnych, w tym decyzji administracyjnych. Natomiast ustalenia ujęte w - zaliczanym do źródeł prawa rozumianych jako akty stanowienia prawa, a dokładniej źródeł prawa sensu largo $^{21}$ - studium uwarunkowań i kierunków zagospodarowania przestrzennego gminy nie moga wywoływać bezpośrednich skutków prawnych w sferze prawa powszechnie obowiąującego, w tym nie moga w sposób bezpośredni kształtować sytuacji prawnej podmiotu nienależącego do struktury organizacyjnej administracji publicznej, a w szczególności nie mogą stanowić podstawy prawnej wydawania rozstrzygnięć zawartych w indywidualnych aktach administracyjnych, w tym decyzji administracyjnych wydawanych na szczeblu lokalnym.

To zaś oznacza, że z uwagi na charakter prawny wskazanych powyżej aktów przejawem władztwa planistycznego gminy jest ustalenie przeznaczenia terenu, a także rozmieszczenie inwestycji celu publicznego oraz określenie sposobów zagospodarowania i warunków zabudowy terenu w - będącym aktem prawa miejscowego - miejscowym planie zagospodarowania przestrzennego, który stanowi podstawę wydawania rozstrzygnięć administracyjnych, $\mathrm{w}$ tym decyzji o pozwoleniu na budowę.

Należy również zauważyć, że - co do zasady - sporządzanie i uchwalanie miejscowych planów zagospodarowania przestrzennego jest fakultatywne ${ }^{22}$, a decyzję w tym zakresie podejmuje rada gminy. Oznacza to, że spora część terytorium kraju nie podlega ustaleniom obowiązujących planów miejscowych, przy czym jak wskazano w regulacji art. 4 ust. 2 u.p.z.p., dla takich gruntów określenie sposobów zagospodarowania i warunków zabudowy terenu następuje w drodze postępowania jurysdykcyjnego, w którym - przy spełnieniu

19 Zob. art. 9 ust. 5 u.p.z.p.

${ }_{20}$ Zob. art. 14 ust. 8 u.p.z.p.

${ }^{21}$ Konstytucja RP z 1997 r. wyróżnia źródła prawa powszechnie obowiązującego oraz źródła prawa o charakterze wewnętrznym. Zatem zgodnie z art. 87 ust. 1 Konstytucji RP - źródłami powszechnie obowiązującego prawa Rzeczypospolitej Polskiej są: Konstytucja, ustawy, ratyfikowane umowy międzynarodowe oraz rozporządzenia. Jak natomiast wskazano w art. 87 ust. 2 Konstytucji RP, źródłami powszechnie obowiązującego prawa Rzeczypospolitej Polskiej są na obszarze działania organów, które je ustanowiły, akty prawa miejscowego. W art. 93 ust. 1 Konstytucji RP do źródeł prawa zaliczono również uchwały Rady Ministrów oraz zarządzenia Prezesa Rady Ministrów i ministrów, wskazując jednocześnie, że mają one charakter wewnętrzny i obowiąują tylko jednostki organizacyjnie podległe organowi wydającemu te akty. Nadto - jak wynika z regulacji art. 142 ust. 1 Konstytucji RP - źródłami prawa o charakterze wewnętrznym obowiązującymi tylko jednostki organizacyjnie podległe organowi wydającemu akt są także zarządzenia Prezydenta RP. Źródła wskazane w Konstytucji RP jako powszechnie obowiązujące są źródłami prawa sensu stricto, a do źródeł prawa sensu largo zalicza się - wskazane w Konstytucji RP - akty prawa wewnętrznego oraz - pominięte w Konstytucji RP - różnorakie formy prawotwórcze (zob. J. Zimmermann, Prawo administracyjne, Kraków 2005, s. 53).

${ }_{22}$ Jak bowiem wskazano w regulacji ujętej w art. 14 ust. 7 u.p.z.p., plan miejscowy sporządza się obowiązkowo wyłącznie wówczas, gdy wymagają tego przepisy. 
określonych przez ustawodawcę przesłanek ustalenia warunków zabudowy i zagospodarowania terenu - może zostać wydana decyzja o warunkach zabudowy i zagospodarowania terenu, która przyjmuje formę albo decyzji o lokalizacji inwestycji celu publicznego ${ }^{23}$ albo decyzji o warunkach zabudowy ${ }^{24}$. To zaś powoduje, że w doktrynie rozważa się, czy ustalenie przeznaczenia, sposobów zagospodarowania i warunków zabudowy terenu w formie aktu administracyjnego, jakim sa wskazane powyżej decyzje lokalizacyjne, mieści się w zakresie użytego przez ustawodawcę $\mathrm{w}$ art. 3 ust. 1 u.p.z.p. - pojęcia ujętego jako „kształtowanie i prowadzenie polityki przestrzennej”, przy czym wskazuje się, że odpowiedź winna być negatywna ${ }^{25}$.

We wskazanych decyzjach lokalizacyjnych - przy założeniu spełnienia przesłanek ich wydania - następuje w szczególności określenie rodzaju inwestycji, a także warunków i szczegółowych zasady zagospodarowania terenu oraz jego zabudowy, przy czym decyzje te są wiążące dla organów wydających decyzje o pozwoleniu na budowę ${ }^{26}$. Wydanie decyzji lokalizacyjnej stanowi zatem dla jej adresata prawnie wiążace i skuteczne erga omnes potwierdzenie, że wskazany teren można zagospodarować $\mathrm{w}$ sposób $\mathrm{w}$ niej ustalony ${ }^{27}$. W związku z powyższym także i wydawanie decyzji o ustaleniu lokalizacji inwestycji celu publicznego, a także decyzji o warunkach zabudowy stanowi przejaw władztwa planistycznego gminy.

Mając zatem na uwadze powyższe, a także okoliczność, że „prowadzenie polityki przestrzennej” nie jest tożsame z „realizacją zadań w zakresie określania przeznaczenia terenu", wskazać należy, że pojęcia te niewątpliwie zazębiaja się ze sobą ${ }^{28}$. Wydaje się bowiem, że realizacja przez organy gminy władztwa

${ }^{23}$ Zgodnie z regulacją art. 4 ust. 2 pkt 1 u.p.z.p. lokalizację inwestycji celu publicznego ustala się w drodze decyzji o lokalizacji inwestycji celu publicznego. Na temat tej decyzji, a także przesłanek jej wydania zob. M. Szewczyk, w: Z. Leoński, M. Szewczyk, M. Kruś, op. cit., s. 191 i n.; K. Małysa-Sulińska, Administracyjnoprawne aspekty inwestycji budowlanych, Warszawa 2012, s. 46 i n. Zob. także M. Szewczyk, Lokalizacja inwestycji publicznych w świetle nowej ustawy o planowaniu i zagospodarowaniu przestrzennym, „Casus” 2003, nr 28, s. 6 i n.; K. Małysa-Sulińska, Zakres przedmiotowy przedsięwzięć, dla których warunki zabudowy i zagospodarowania terenu określane sq $w$ formie decyzji o ustaleniu lokalizacji inwestycji celu publicznego, „Casus” 2009, nr 53, s. 6 i n.

${ }^{24}$ Zgodnie z regulacją art. 4 ust. 2 pkt 2 u.p.z.p. sposób zagospodarowania terenu i warunki zabudowy dla inwestycji niekwalifikowanych jako inwestycja celu publicznego ustala się w drodze decyzji o warunkach zabudowy. Na temat tej decyzji, a także przesłanek jej wydania zob. M. Szewczyk, w: Z. Leoński, M. Szewczyk, M. Kruś, op. cit., s. 191 i n.; K. Małysa-Sulińska, Administracyjnoprawne aspekty..., s. 95 i n.

${ }^{25}$ Tak Z. Niewiadomski (red.) et al., op. cit., s. 32-33.

${ }^{26}$ Zob. art. 55 u.p.z.p., zgodnie z którym decyzja o ustaleniu lokalizacji inwestycji celu publicznego wiąże organ wydający decyzję o pozwoleniu na budowę, a przepis ten - jak wskazano w art. 64 ust. 1 u.p.z.p. - stosuje się odpowiednio do decyzji o warunkach zabudowy.

${ }^{27}$ Zob. M. Szewczyk, w: Z. Leoński, M. Szewczyk, M. Kruś, op. cit., s. 58.

${ }^{28}$ Tak Z. Niewiadomski (red.) et al., Planowanie..., s. 33. Wskazuje się także, iż „Kształtowanie polityki przestrzennej to analizowanie potrzeb $\mathrm{w}$ zakresie planowania i zagospodarowania przestrzennego i ustalanie kierunków polityki przestrzennej gminy, zwłaszcza w studium uwarunkowań i kierunków polityki przestrzennej gminy. Prowadzenie tej polityki to ustalanie miejscowych planów zagospodarowania przestrzennego, a także analizowanie potrzeb zmiany studium i planu miejscowego" - tak: A. Plucińska-Filipowicz, T. Filipowicz, w: M. Wierzbowski, A. Plucińska-Filipowicz (red.) et al., op. cit., s. 63. 
planistycznego, jeśli ma prowadzić do zagospodarowania terenu spójnego z polityka przestrzenna prowadzoną na wszystkich szczeblach planowania, musi podlegać ograniczeniom. Ustawodawca ograniczenia takie wprowadza, a część $\mathrm{z}$ nich powiązana jest $\mathrm{z}$ pozostawaniem $\mathrm{w}$ obrocie prawnym ramowego studium uwarunkowań i kierunków zagospodarowania przestrzennego związku metropolitalnego. Władztwo planistyczne gminy nie może bowiem oznaczać jej całkowitej autonomii w tym zakresie, przy czym jego zakres określa nie gmina, ale ustawodawca ${ }^{29}$.

\section{ZAKRES TERYTORIALNY RAMOWEGO STUDIUM UWARUNKOWAŃ I KIERUNKÓW ZAGOSPODAROWANIA PRZESTRZENNEGO ZWIĄZKU METROPOLITALNEGO}

Ramowe studium uwarunkowań i kierunków zagospodarowania przestrzennego związku metropolitalnego sporządza się - jak wprost wskazano w regulacji art. 37o ust. 1 u.p.z.p.z. - dla całego obszaru metropolitalnego. Oznacza to, że przedmiotowy akt powinien obejmować swym zasięgiem powierzchnię wszystkich jednostek samorządu terytorialnego wchodzących w skład związku metropolitalnego.

Mając na uwadze przywołaną regulację ustawowa, należy wykluczyć możliwość uchwalenia studium metropolitalnego tylko dla części obszaru związku. Niedopuszczalne jest również objęcie ustaleniami ramowego studium uwarunkowań i kierunków zagospodarowania przestrzennego związku metropolitalnego obszarów położonych poza granicami jednostek samorządu terytorialnego wchodzących w skład związku metropolitalnego ${ }^{30}$. Wykluczyć należy także etapowanie prac nad studium metropolitalnym, które z założenia powinno być opracowaniem kompleksowym, obejmującym cały obszar związku metropolitalnego. To zaś oznacza, że na obszarze metropolitalnym może obowiązywać wyłącznie jedno ramowe studium uwarunkowań i kierunków zagospodarowania przestrzennego związku metropolitalnego.

Ograniczenie zakresu ramowego studium uwarunkowań i kierunków zagospodarowania przestrzennego związku metropolitalnego do granic administracyjnych jednostek wchodzących w skład związku nie oznacza jednak, że opracowanie to funkcjonuje w oderwaniu od uwarunkowań przestrzennych występujacych poza tymi granicami. Studium to kształtuje wprawdzie polityke przestrzenna na obszarze metropolitalnym, ale jest ona determinowana ustaleniami zawartymi w ponadlokalnych aktach planowania, których zakres wykracza poza obszar związku metropolitalnego.

${ }_{29}$ Por. H. Izdebski, w: idem, I. Zachariasz, Ustawa o planowaniu i zagospodarowaniu przestrzennym. Komentarz, Warszawa 2013, s. 64.

${ }^{30}$ Jak bowiem wynika z regulacji art. 3 ust. 2 a u.p.z.p.z., do zadań związku metropolitalnego należy kształtowanie i prowadzenie polityki przestrzennej wyłącznie na obszarze związku metropolitalnego (obszarze metropolitalnym). 
W treści ramowego studium uwarunkowań i kierunków zagospodarowania przestrzennego związku metropolitalnego należy uwzględnić bowiem ustalenia planu zagospodarowania przestrzennego województwa, a w przypadku braku planu wojewódzkiego lub niewprowadzenia do tego planu zadań rządowych - ustalenia programów zawierających zadania rządowe służące realizacji inwestycji celu publicznego o znaczeniu krajowym ${ }^{31}$.

Powyższe powoduje, że w postępowaniu, którego celem jest sporządzenie i uchwalenie ramowego studium uwarunkowań i kierunków zagospodarowania przestrzennego związku metropolitalnego uczestnicza organy jednostek samorządu terytorialnego oraz administracji rządowej, a ich rozstrzygnięcia moga determinować treść tego opracowania planistycznego. Zatem zarząd województwa jest właściwy w zakresie uzgodnienia projektu studium metropolitalnego w zakresie jego zgodności z ustaleniami planu zagospodarowania przestrzennego województwa ${ }^{32}$, a wojewoda dokonuje uzgodnienia tego projektu w zakresie zgodności z ustaleniami programów zawierających zadania rządowe służace realizacji inwestycji celu publicznego o znaczeniu krajowym ${ }^{33}$.

Nadto wojewoda może wezwać zgromadzenie związku metropolitalnego do uchwalenia lub zmiany ramowego studium uwarunkowań i kierunków zagospodarowania przestrzennego związku metropolitalnego, jeśli studium nie zostało uchwalone bądź nie uwzględniono w nim obszarów rozmieszczenia inwestycji celu publicznego o znaczeniu krajowym i wojewódzkim ujętych w planach wojewódzkich bądź programach rządowych ${ }^{34}$.

\section{TREŚĆ I FUNKCJA STUDIUM UWARUNKOWAŃ I KIERUNKÓW ZAGOSPODAROWANIA PRZESTRZENNEGO ZWIĄZKU METROPOLITALNEGO}

W doktrynie wskazuje się, że istota ramowego studium uwarunkowań i kierunków zagospodarowania przestrzennego związku metropolitalnego sprowadza się do ustalenia wspólnej strategii rozwoju dla jednostek samorządu terytorialnego wchodzących w skład związku metropolitalnego w celu jej uwzględnienia w studiach gminnych, realizacji zadań przekazanych temu związkowi przez jednostki będące jego członkami, a także pozyskiwania środ-

${ }^{31}$ Zob. art. 11 pkt $4 \mathrm{w}$ zw. z art. 370 ust. 8 u.p.z.p.

32 Zob. art. 11 pkt $6 \mathrm{w}$ zw. z art. 380 ust. 1 u.p.z.p.

${ }^{33}$ Zob. art. 11 pkt $6 \mathrm{w}$ zw. z art. 37 o ust. 8 u.p.z.p.

${ }^{34}$ Zob. art. 12 ust. 3 w zw. z art. 37o ust. 8 u.p.z.p. Należy natomiast wykluczyć taką interpretację odesłania do odpowiedniego stosowania regulacji art. 37o ust. 8 u.p.z.p. do ramowego studium uwarunkowań i kierunków zagospodarowania przestrzennego związku metropolitalnego, zgodnie z którą wojewoda po bezskutecznym upływie wyznaczonego terminu na uchwalenie lub dokonanie zmiany studium metropolitalnego jest uprawniony do sporządzenia miejscowego planu zagospodarowania przestrzennego albo jego zmiany w zakresie koniecznym, aby umożliwić realizację inwestycji celu publicznego. Brak bowiem uzasadnienia przekazania kompetencji rady gminy wojewodzie w przypadku zaniechań leżących po stronie organów związku metropolitalnego. 
ków finansowych na realizację tych zadań ${ }^{35}$. Należy jednak zauważyć, że z uwagi na okoliczność, iż ramowe studium uwarunkowań i kierunków zagospodarowania przestrzennego związku metropolitalnego sporządzane jest z uwzględnieniem ustaleń planu zagospodarowania przestrzennego województwa ${ }^{36}$, względnie w przypadku braku planu wojewódzkiego lub niewprowadzenia do tego planu zadań rządowych - z uwzględnieniem ustaleń programów zawierających zadania rządowe służące realizacji inwestycji celu publicznego o znaczeniu krajowym, w opracowaniu tym następuje również adaptacja do potrzeb obszaru metropolitalnego części ustaleń planu zagospodarowania przestrzennego województwa, względnie programów rządowych.

W ramowym studium uwarunkowań i kierunków zagospodarowania przestrzennego związku metropolitalnego określa się więc: zasady i obszary rozwoju systemów komunikacji, w tym dróg publicznych z podziałem na klasy i kategorie, infrastruktury technicznej oraz rozmieszczenie innych inwestycji celu publicznego o znaczeniu metropolitalnym ${ }^{37}$; zasady i obszary ochrony środowiska, przyrody i krajobrazu, ponadregionalnych i regionalnych korytarzy ekologicznych, ochrony uzdrowisk oraz dziedzictwa kulturowego i zabytków oraz dóbr kultury współczesnej, mających znaczenie dla całości obszaru metropolitalnego, w szczególności w odniesieniu do sposobów realizacji infrastruktury technicznej ${ }^{38}$; ustalenia wynikające z zasad rozwoju i ochrony obszarów, o których mowa powyżej, położonych w granicach obszaru metropolitalnego ${ }^{39}$; maksymalne powierzchnie przeznaczone pod zabudowę ${ }^{40}, \mathrm{z}$ podziałem na rodzaje zabudowy oraz gminy ${ }^{41}$. Podkreślić trzeba przy tym, że wskazane ustalenia studium metropolitalnego obejmuja jedynie elementy niezbędne dla właściwego ukierunkowania polityki przestrzennej gmin należących do związku, ze względu na spójność przestrzenną i społeczno-gospodarczą obszaru metropolitalnego ${ }^{42}$. Ujęcie zatem w tym studium rozwiązań, które nie moga być kwalifikowane jako niezbędne w rozumieniu regulacji art. 37o ust. 5 u.p.z.p., może prowadzić do nieuzasadnionego ograniczenia swobody planistycznej gmin wchodzaccych w skład związku, a to z kolei winno skutko-

${ }^{35}$ Zob. A. Plucińska-Filipowicz, A. Kosicki, w: M. Wierzbowski, A. Plucińska-Filipowicz (red.) et al., op. cit., s. 461.

${ }^{36}$ Zob. art. 370 ust. 1 u.p.z.p.

${ }^{37}$ Zob. art. 37 o ust. 2 pkt 1 u.z.p.z.

${ }^{38}$ Zob. art. 37 o ust. 2 pkt 2 u.z.p.z.

${ }^{39}$ Zob. art. 37 o ust. 2 pkt 3 u.z.p.z.

${ }^{40}$ Przy określaniu tych powierzchni należy mieć na uwadze-zgodnie z regulacją art. 37o ust. 3 u.p.z.p. - potrzeby i możliwości rozwojowe obszaru metropolitalnego uwzględniające w szczególności: (pkt 1) analizy ekonomiczne, środowiskowe i społeczne; (pkt 2) prognozy demograficzne, w tym uwzględniające migracje w ramach obszaru metropolitalnego; (pkt 3) możliwości finansowania przez gminy oraz związek metropolitalny wykonania sieci komunikacyjnej i infrastruktury technicznej, a także infrastruktury społecznej, służących realizacji zadań własnych odpowiednio tych jednostek; (pkt 4) bilans terenów przeznaczonych pod zabudowę, przy czym - jak wskazano w art. 370 ust. 4 u.p.z.p.z. - dokonując tego bilansu, stosuje się odpowiednio przepisy dotyczace studium uwarunkowań i kierunków zagospodarowania przestrzennego w gminie (zob. art. 10 ust. 5, 6 i 7 u.p.z.p.z. z komentarzem T. Filipowicza, w: M. Wierzbowski, A. Plucińska-Filipowicz (red.) et al., op. cit., s. 156-159).

${ }^{41}$ Zob. art. 37o ust. 2 pkt 4 u.z.p.z.

${ }^{42}$ Zob. art. 37 o ust. 5 u.z.p.z. 
wać ich wyeliminowaniem z obrotu prawnego ${ }^{43}$, choć - jak podnosi się $\mathrm{w}$ doktrynie - w praktyce identyfikacja tych „elementów niezbędnych” może budzić wątpliwości i być kłopotliwa ${ }^{44}$.

Podstawową funkcją ramowego studium uwarunkowań i kierunków zagospodarowania przestrzennego związku metropolitalnego jest zatem kształtowanie polityki przestrzennej $j^{45}$ na obszarze metropolitalnym. Funkcja ta wynika $\mathrm{z}$ charakteru przedmiotowego opracowania planistycznego, które jest aktem polityki przestrzennej związku metropolitalnego. Mając zaś na uwadze okoliczność, że kształtowanie polityki przestrzennej na danym obszarze nie jest możliwe bez uwzględnienia kierunków rozwoju gospodarczego, wydaje się, iż studium metropolitalne - podobnie jak studium uwarunkowań i kierunków zagospodarowania przestrzennego gminy ${ }^{46}$ - może być kwalifikowane nie tylko jako akt polityki przestrzennej związku metropolitalnego, lecz także polityki rozwoju przestrzenno-gospodarczego na obszarze metropolitalnym.

Funkcją ramowego studium uwarunkowań i kierunków zagospodarowania przestrzennego związku metropolitalnego jest również koordynacja - niezbędnych dla właściwego ukierunkowania polityki przestrzennej gmin należących do związku, ze względu na spójność przestrzenna i społeczno-gospodarczą obszaru metropolitalnego - ustaleń ujętych w studiach uwarunkowań i kierunków zagospodarowania przestrzennego gmin wchodzących w skład związku metropolitalnego. Studium metropolitalne stanowi zatem wytyczne integracji przestrzeni obszaru metropolitalnego, na który składa się teren więcej niż jednej jednostki samorządu terytorialnego. W wyniku uchwalenia ramowego studium uwarunkowań i kierunków zagospodarowania przestrzennego związku metropolitalnego następuje bowiem przyjęcie ustaleń wiążących w kształtowaniu gminnej polityki przestrzennej ${ }^{47}$.

Można wskazać, że funkcja ramowego studium uwarunkowań i kierunków zagospodarowania przestrzennego związku metropolitalnego - podobnie jak studium gminnego ${ }^{48}$ - jest także promocja obszaru metropolitalnego. Funkcja promocyjna omawianego opracowania planistycznego jest związana

${ }^{43}$ Por. A. Plucińska-Filipowicz, A. Kosicki, w: M. Wierzbowski, A. Plucińska-Filipowicz (red.) et al., op. cit., s. 461.

${ }^{44}$ Zob. K. Borówka, J. Szlachetko, Ramowe studium uwarunkowań i kierunków zagospodarowania przestrzennego zwiazku metropolitalnego. Analiza dogmatycznoprawna, „Metropolitan. Przegląd Naukowy" 2016, nr 2, s. 32.

${ }^{45}$ Polityka przestrzenna zajmuje się definiowaniem interesów publicznych oraz określaniem sposobów oddziaływania na zachowania uczestników procesów zagospodarowania przestrzennego, tak aby dokonywali wyborów zgodnie z interesem publicznym - zob. Z. Niewiadomski (red.) et al., Ustawa o planowaniu i zagospodarowaniu przestrzennym. Komentarz, Warszawa 2005, s. 81.

${ }^{46} \mathrm{Na}$ temat studium uwarunkowań i kierunków zagospodarowania przestrzennego gminy jako aktu polityki przestrzennej oraz polityki rozwoju gminy zob. Z. Niewiadomski, Planowanie przestrzenne - zarys systemu, Warszawa 2003, s. 92 i n.

${ }_{47}$ Zob. art. 37o ust. 6 u.p.z.p., zgodnie z którym ustalenia ramowego studium uwarunkowań i kierunków zagospodarowania przestrzennego związku metropolitalnego, o których mowa w ust. 2 pkt 3-4 u.p.z.p., są wiążące dla wójta (burmistrza albo prezydenta miasta) przy sporządzaniu studium uwarunkowań i kierunków zagospodarowania przestrzennego gminy.

${ }^{48} \mathrm{Na}$ temat funkcji promocyjnej studium uwarunkowań i kierunków zagospodarowania przestrzennego gminy zob. Z. Niewiadomski, op. cit., s. 92-93. 
z jego ustaleniami, gdyż w studium - przez wskazanie związanych z polityka przestrzenną np. ustaleń wynikajacych z zasad rozwoju i ochrony obszarów uzdrowisk oraz dziedzictwa kulturowego i zabytków, a także dóbr kultury współczesnej - informuje się o koncepcji rozwoju przestrzenno-gospodarczego obszaru metropolitalnego, przy czym jeśli ta koncepcja jawi się jako atrakcyjna w ocenie jednostki, to atrakcyjna jest dla niej również możliwość związania się z danym obszarem czy to przez zamieszkanie, czy też inwestowanie.

Mając na uwadze treść i wynikające z niej funkcje ramowego studium uwarunkowań i kierunków zagospodarowania przestrzennego związku metropolitalnego, należy zauważyć, że powinno to być opracowanie stwarzające maksymalne możliwości uwzględniania przy planowaniu lokalnym aktualnych warunków i potrzeb obszaru metropolitalnego. Dlatego też studium metropolitalne podlega systematycznej ocenie aktualności ${ }^{49}$.

\section{WYMÓG UWZGLĘDNIENIA USTALEŃ RAMOWEGO STUDIUM UWARUNKOWAŃ I KIERUNKÓW ZAGOSPODAROWANIA PRZESTRZENNEGO ZWIAZZKU METROPOLITALNEGO W TREŚCI STUDIUM UWARUNKOWAŃ I KIERUNKÓW ZAGOSPODAROWANIA PRZESTRZENNEGO GMINY}

Zgodnie z rozwiązaniami przyjętymi przez ustawodawcę ustalenia - sporządzanego dla obszaru metropolitalnego - ramowego studium uwarunkowań i kierunków zagospodarowania przestrzennego związku metropolitalnego powinny zostać uwzględnione w studium uwarunkowań i kierunków zagospodarowania przestrzennego gminy. Tak więc wójt (burmistrz lub prezydent miasta), odpowiedzialny za przebieg gminnego postępowania planistycznego, został zobligowany do uwzględnienia ustaleń studium metropolitalnego w toku prac zmierzających do sporządzenia projektu studium uwarunkowań i kierunków zagospodarowania przestrzennego gminy ${ }^{50}$, co winno skutkować ich ujęciem w projekcie tego studium gminnego ${ }^{51}$.

Powyższe oznacza, że sporządzony w toku procedury planistycznej projekt studium gminnego nie może być niezgodny z ustaleniami ramowego studium uwarunkowań i kierunków zagospodarowania przestrzennego związku metropolitalnego, przy czym weryfikacji w tym zakresie dokonuje zarząd związku

${ }^{49}$ Zob. art. 37o ust. 8 w zw. z art. 32 u.p.z.p. Zgodnie z przywołaną regulacją w celu oceny aktualności studium metropolitalnego należy dokonać analiz zmian w zagospodarowaniu przestrzennym obszaru metropolitalnego, a ich wyniki zarząd związku metropolitalnego winien przekazać zgromadzeniu związku, który to organ podejmuje uchwałę w sprawie aktualności studium, a w przypadku uznania go za nieaktualne - podejmuje działania mające na celu jego zmianę.

50 Należy zauważyć, że wójt (burmistrz lub prezydent miasta) nie jest zobligowany do osobistego sporządzenia projektu studium uwarunkowań i kierunków zagospodarowania przestrzennego gminy. Ustawodawca zobowiązał natomiast organ wykonawczy w gminie do powierzenia opracowania projektu studium gminnego osobom posiadajacym odpowiednie kwalifikacje, o których mowa w art. 5 u.p.z.p. Szerzej na ten temat zob. M. Wierzbowski, A. Plucińska-Filipowicz (red.) et al., op. cit., s. 128.

${ }^{51}$ Por. art. 9 ust. 2 i art. 11 pkt 4 u.p.z.p. 
metropolitalnego. Organ wykonawczy związku metropolitalnego jest bowiem właściwy w przedmiocie uzgodnienia projektu studium uwarunkowań i kierunków zagospodarowania przestrzennego gminy w zakresie jego zgodności ze studium metropolitalnym ${ }^{52}$, przy czym należy zauważyć, że podstawą do dokonania takiego uzgodnienia może być wyłącznie przyjęte studium metropolitalne, a nie jego projekt. Wydaje się również, że brak uzasadnienia występowania przez wójta (burmistrz lub prezydent miasta) do zarządu związku metropolitalnego o uzgodnienie projektu studium gminnego, gdy w obrocie prawnym nie pozostaje ramowe studium uwarunkowań i kierunków zagospodarowania przestrzennego związku metropolitalnego. Niecelowe jest bowiem uczestniczenie zarządu związku metropolitalnego w przedmiotowym postępowaniu planistycznym w przypadku, gdy nie uchwalono jeszcze studium metropolitalnego.

Organem kontrolujacym procedurę planistyczną i podjęte rozstrzygnięcie w postępowaniu zakończonym uchwaleniem studium uwarunkowań i kierunków zagospodarowania przestrzennego gminy jest zaś wojewoda. Wójt (burmistrz lub prezydent miasta) jest bowiem zobligowany przedstawić wojewodzie uchwałę rady gminy o uchwaleniu studium gminnego wraz z załącznikami oraz dokumentacja prac planistycznych ${ }^{53} \mathrm{w}$ celu oceny ich zgodności z przepisami prawnymi ${ }^{54}$. Podkreślenia wymaga, że wojewoda ocenia zgodność z przepisami prawnymi nie tylko uchwały rady gminy w przedmiocie studium, ale także - przez analizę dokumentacji prac planistycznych - całego postępowania planistycznego, a oceny tej dokonuje w trybie zasad ogólnych traktujacych o nadzorze nad działalnościa samorządu gminy ${ }^{55}$. Oznacza to, że dokonując kontroli przedmiotowego postępowania planistycznego, wojewoda bada m.in., czy w toku tego postępowania wymagane było uzgodnienie przez zarząd związku metropolitalnego projektu studium uwarunkowań i kierunków zagospodarowania przestrzennego gminy w zakresie jego zgodności ze studium metropolitalnym i czy uzgodnienie takie nastapiło. Jak bowiem wskazano w regulacji art. 28 ust. 1 u.p.z.p., istotne naruszenie zasad sporządzania studium uwarunkowań i kierunków zagospodarowania przestrzennego gminy, istotne naruszenie trybu jego sporządzania, a także naruszenie właściwości organów w tym zakresie powoduja nieważność uchwały rady gminy w całości lub części.

Trzeba zauważyć, że studium uwarunkowań i kierunków zagospodarowania przestrzennego gminy nie jest aktem prawa miejscowego, co oznacza, że nie ma ono mocy powszechnie obowiązującej, a w związku z tym nie może w sposób bezpośredni kształtować sytuacji prawnej jednostki znajdującej się

${ }^{52}$ Por. art. 11 pkt 6 u.p.z.p.

${ }^{53}$ Zgodnie z $§ 12$ pkt 4 rozporządzenia Ministra Infrastruktury z 28 kwietnia 2004 r. w sprawie zakresu projektu studium uwarunkowań i kierunków zagospodarowania przestrzennego gminy (Dz. U. Nr 118, poz. 1233) przez dokumentację prac planistycznych należy rozumieć zbiór dokumentów, które powstały w procesie sporządzania i uchwalania projektu studium uwarunkowań i kierunków zagospodarowania przestrzennego gminy.

${ }_{54}$ Zob. art. 12 ust. 2 u.p.z.p.

${ }_{55}$ Szerzej na ten temat zob. B. Dolnicki (red.) et al., Ustawa o samorzadzie gminnym. Komentarz, Warszawa 2016, Lex/el., ad art. 85 i n. 
poza struktura organizacyjną administracji publicznej. Jego ustalenia winny być jednak uwzględnione w treści - stanowiącego źródło prawa powszechnie obowiązującego na obszarze gminy ${ }^{56}$ - miejscowego planu zagospodarowania przestrzennego ${ }^{57}$. Powyższe oznacza zaś, że ustalenia przetransponowane ze studium metropolitalnego do studium gminnego wywołuja skutki prawne dla obywateli, ale dopiero z chwilą wejścia w życie planu miejscowego, wydanego z uwzględnieniem ustaleń studium uwarunkowań i kierunków zagospodarowania przestrzennego gminy. Ustalenia tego - będącego aktem prawa miejscowego - planu stanowią bowiem podstawę prawną wydawania rozstrzygnięć zawartych $\mathrm{w}$ indywidualnych aktach administracyjnych, $\mathrm{w}$ tym decyzji administracyjnych.

\section{ZARZĄDZENIE ZASTĘPCZE WOJEWODY \\ W PRZEDMIOCIE MIEJSCOWEGO PLANU \\ ZAGOSPODAROWANIA PRZESTRZENNEGO \\ JAKO KONSEKWENCJA NIEUWZGLĘDNIENIA USTALEŃ \\ RAMOWEGO STUDIUM UWARUNKOWAŃ I KIERUNKÓW \\ ZAGOSPODAROWANIA PRZESTRZENNEGO ZWIĄZKU \\ METROPOLITALNEGO W TREŚCI STUDIUM UWARUNKOWAŃ I KIERUNKÓW ZAGOSPODAROWANIA PRZESTRZENNEGO GMINY}

Wojewoda - poza podejmowaniem wskazanych powyżej czynności kontrolnych $\mathrm{w}$ toku procedury planistycznej zmierzajacej do uchwalenia studium gminnego - weryfikuje również treść pozostającego w obrocie studium uwarunkowań i kierunków zagospodarowania przestrzennego gminy pod kątem uwzględnienia $\mathrm{w}$ nim obszarów rozmieszczenia inwestycji celu publicznego ujętych w ramowym studium uwarunkowań i kierunków zagospodarowania przestrzennego związku metropolitalnego. Jeżeli bowiem w uchwalonym studium gminnym nie określono - ujętych w studium metropolitalnym - obszarów rozmieszczenia inwestycji celu publicznego, wojewoda może sporządzić miejscowy plan zagospodarowania przestrzennego albo jego zmianę w zakresie koniecznym dla możliwości realizacji inwestycji celu publicznego o znaczeniu metropolitalnym ${ }^{58}$.

$\mathrm{Z}$ regulacji art. 12 ust. 3 u.p.z.p. wynika zatem, że w sytuacji nieuwzględnienia ustaleń ramowego studium uwarunkowań i kierunków zagospodarowania przestrzennego związku metropolitalnego w treści studium uwarunkowań i kierunków zagospodarowania przestrzennego gminy, ustawodawca dopuszcza możliwość odjęcia organom gminy uprawnień w zakresie kształtowania ładu przestrzennego i przekazania kompetencji w przedmiocie sporządzenia

${ }^{56}$ Zob. regulację art. 14 ust. 8 u.p.z.p., zgodnie z która miejscowy plan zagospodarowania przestrzennego jest aktem prawa miejscowego.

${ }_{57}$ Zob. art. 15 ust. 1 u.p.z.p.

${ }^{58}$ Por. art. 12 ust. 3 u.p.z.p. 
miejscowego planu zagospodarowania przestrzennego organowi administracji rządowej, jakim jest wojewoda ${ }^{59}$. W omawianym przypadku wojewoda po podjęciu czynności zmierzających do uzgodnienia terminu realizacji wskazanych inwestycji celu publicznego i warunków ich wprowadzenia do studium uwarunkowań i kierunków zagospodarowania przestrzennego gminy wzywa radę gminy do zmiany studium gminnego w wyznaczonym terminie. Bezskuteczny upływ zakreślonego terminu skutkuje zaś podjęciem przez wojewodę czynności planistycznych zmierzających do sporządzenia miejscowego planu zagospodarowania przestrzennego. Celem tych czynności wojewody jest uwzględnienie - ujętych w ramowym studium uwarunkowań i kierunków zagospodarowania przestrzennego związku metropolitalnego - inwestycji celu publicznego, lecz nie w studium gminnym, ale w planie miejscowym. Wojewoda sporządza zatem miejscowy plan zagospodarowania przestrzennego albo jego zmianę dla obszaru, którego dotyczy wskazane powyżej zaniechanie rady gminy, w zakresie koniecznym do możliwości realizacji - ujętej w ramowym studium uwarunkowań i kierunków zagospodarowania przestrzennego związku metropolitalnego - inwestycji celu publicznego. Podkreślić więc należy, że sporządzenie planu miejscowego przez wojewodę w trybie art. 12 ust. 3 u.p.z.p. nie znajduje uzasadnienia, gdy w uchwalonym studium gminnym nie uwzględniono innych poza wskazanymi powyżej inwestycjami celu publicznego ustaleń studium metropolitalnego. Niedopuszczalne jest również sporządzenie miejscowego planu zagospodarowania przestrzennego przez wojewodę wówczas, gdy gmina, działając na jego wezwanie, uchwaliła studium uwarunkowań i kierunków zagospodarowania przestrzennego gminy lub dokonała jego zmiany, ale jednocześnie nie sporządziła stosownego planu miejscowego.

Trzeba przy tym zauważyć, że miejscowy plan zagospodarowania przestrzennego sporządzony przez wojewodę i wprowadzony do obrotu prawnego w drodze zarządzenia zastępczego wywołuje skutki prawne tożsame z planem miejscowym sporządzonym przez wójta (burmistrza lub prezydenta miasta), a uchwalonym przez radę gminy ${ }^{60}$. W związku z powyższym wejście w życie, uwzględniajaccego ustalenia ramowego studium uwarunkowań i kierunków zagospodarowania przestrzennego związku metropolitalnego, miejscowego planu zagospodarowania przestrzennego sporządzonego przez wojewodę powoduje, że moc wiążącą tracą inne plany miejscowe lub ich części odnoszące się do objętego nim terenu ${ }^{61}$. Oznacza to zatem, że to plan miejscowy sporzą-

59 Poza wskazanym przypadkiem nieuwzględnienia ustaleń ramowego studium uwarunkowań i kierunków zagospodarowania przestrzennego związku metropolitalnego w treści studium uwarunkowań i kierunków zagospodarowania przestrzennego gminy, ustawodawca - jak wskazano w regulacji art. 12 ust. 3 u.p.z.p. - dopuszcza możliwość odjęcia gminie uprawnień w zakresie kształtowania ładu przestrzennego i przekazania kompetencji w przedmiocie sporządzenia miejscowego planu zagospodarowania przestrzennego wojewodzie także i wówczas, gdy rada gminy nie uchwaliła studium, nie przystapiła do jego zmiany albo uchwalając studium, nie określiła w nim obszarów rozmieszczenia inwestycji celu publicznego o znaczeniu krajowym bądź wojewódzkim ujętych w planie zagospodarowania przestrzennego województwa bądź w programie zawierajacym zadania rządowe służące realizacji inwestycji celu publicznego o znaczeniu krajowym.

${ }_{60}$ Zob. art. 12 ust. 3 in fine u.p.z.p.

61 Zob. art. 34 ust. 1 u.p.z.p. 
dzony - w trybie art. 12 ust. 3 u.p.z.p. - przez wojewodę stanowi podstawę wydawania rozstrzygnięć zawartych w indywidualnych aktach administracyjnych, w tym decyzji administracyjnych.

\section{PODSUMOWANIE I WNIOSKI}

Ramowe studium uwarunkowań i kierunków zagospodarowania przestrzennego związku metropolitalnego nie jest aktem prawa miejscowego ${ }^{62}$, co oznacza, że nie ma ono mocy powszechnie obowiązującej. W związku z powyższym ustalenia studium metropolitalnego nie moga wywoływać bezpośrednich skutków prawnych w sferze prawa powszechnie obowiąujacego, w tym nie moga w sposób bezpośredni kształtować sytuacji prawnej jednostki, a w szczególności nie mogą stanowić podstawy prawnej wydawania rozstrzygnięć zawartych w indywidualnych aktach administracyjnych, w tym decyzji administracyjnych, którymi są również decyzja o ustaleniu lokalizacji inwestycji celu publicznego, a także decyzja o warunkach zabudowy, wydawane, gdy na danym terenie nie obowiązuje miejscowy plan zagospodarowania przestrzennego.

Ustalenia ramowego studium uwarunkowań i kierunków zagospodarowania przestrzennego związku metropolitalnego - jak już wskazano powyżej - powinny być jednak uwzględniane przez organy właściwe w przedmiocie uchwalenia i zmiany studium uwarunkowań i kierunków zagospodarowania przestrzennego gminy. Organy te sa bowiem zobligowane do sporządzenia i uchwalenia takiego studium gminnego, którego treść jest zgodna z ustaleniami studium metropolitalnego, a nadto do weryfikacji pod kątem zgodności $\mathrm{z}$ ustaleniami studium metropolitalnego, pozostającego $\mathrm{w}$ obrocie prawnym studium gminnego. Oznacza to, że ustalenia ramowego studium uwarunkowań i kierunków zagospodarowania przestrzennego związu metropolitalnego przez skierowanie ich do wassko określonej kategorii adresatów będących organami administracji publicznej są wiążące w strukturze organizacyjnej tej administracji. Zawierają one przy tym ustalenia wskazujące obraną przez związek metropolitalny politykę przestrzenną na jego obszarze, które - w ocenie autorki niniejszego opracowania - zaliczają się do szczególnej kategorii norm prawa administracyjnego, jaka stanowią normy kształtujace ład przestrzenny ${ }^{63}$. W tym miejscu należy zauważyć, że przypisane do danej przestrzeni normy kształtujace ład przestrzenny oddziałują na siebie, gdyż kompleksowe traktowanie występujacych na danym terenie zagadnień dotyczacych planowania przestrzennego nakazuje uwzględniania ich w różnych skalach,

${ }^{62}$ Zob. art. 370 ust. 7 u.p.z.p.

${ }^{63}$ Normy kształtujące ład przestrzenny są w znacznym stopniu konkretne w odniesieniu do regulowanej sytuacji, a jednocześnie w znaczącym zakresie abstrakcyjne. Ich konkretność polega na tym, że odnoszą się one do konkretnie oznaczonego terenu, a abstrakcyjność tej kategorii norm prawa wynika z konieczności konkretyzacji ich zapisów w normach zawartych w innych aktach planowania przestrzennego lub w decyzjach administracyjnych (szerzej na ten temat zob. K. Małysa-Sulińska, Normy..., s. 57 i n.). 
a to: krajowej, wojewódzkiej i gminnej, a w przypadku istnienia na danym obszarze związku metropolitalnego - również w skali metropolitalnej. Podkreślić trzeba bowiem, że każde szczegółowe rozwiązanie planistyczne w skali gminy stanowi wyłącznie wycinek tego zagadnienia w skali kraju, województwa czy też obszaru metropolitalnego, a w związku z tym normy odnoszace się do przeznaczenia danego terenu nie mogą być ze sobą sprzeczne.

Majac na uwadze powyższe, należy wskazać, że ustalenia ramowego studium uwarunkowań i kierunków zagospodarowania przestrzennego związku metropolitalnego pośrednio kształtują sytuację prawną podmiotów znajdujących się na zewnątrz struktury organizacyjnej administracji publicznej. Determinują one bowiem treść ustaleń ujętych w gminnych aktach planistycznych, w tym również w akcie prawa miejscowego, którym jest miejscowy plan zagospodarowania przestrzennego, jeśli taki zostanie uchwalony i wejdzie do obrotu prawnego. Podkreślenia wymaga bowiem, że ustalenia ujęte w studium metropolitalnym wywołuja skutki prawne dla obywateli dopiero po przetransponowaniu ich treści do miejscowego planu zagospodarowania przestrzennego, co następuje albo przez wcześniejsze uszczegółowienie ich treści w studium gminnym, albo - jeśli w obrocie prawnym nie pozostaje studium gminne lub nie określono w nim obszarów rozmieszczenia inwestycji celu publicznego ujętych $\mathrm{w}$ studium metropolitalnym - w planie miejscowym sporządzonym przez wojewodę w trybie art. 12 ust. 3 u.p.z.p. ${ }^{64}$, które stanowią wytyczne dla kształtu ustaleń ujętych w planie miejscowym ${ }^{65}$.

Przyjęte przez ustawodawcę rozwiązanie, zgodnie z którym akty planistyczne tworzą wielopoziomowy system ze spójnymi treściowo ${ }^{66}$ opracowaniami na szczeblu: kraju, województwa, obszaru metropolitalnego oraz gminy, powoduje, że ramowe studium uwarunkowań i kierunków zagospodarowania przestrzennego związku metropolitalnego jest nie tylko aktem określajacym politykę przestrzenną na obszarze metropolitalnym, lecz także narzędziem ograniczajaccym władztwo planistyczne gminy. Wynika to z okoliczności, że organy właściwe w zakresie sporządzenia i uchwalenia gminnych aktów planistycznych są związane bezpośrednio lub pośrednio ustaleniami ujętymi w studium metropolitalnym i nie maja żadnej autonomii w zakresie ich niezastosowania. To zaś może skutkować tym, że wskazany w - stanowiacym podstawę prawną podejmowania rozstrzygnięć ujętych w indywidualnych aktach

${ }^{64}$ Należy jednak zauważyć, że w doktrynie wyrażono pogląd o bezpośrednim związaniu rady gminy w procedurze planistycznej mającej na celu uchwalenie miejscowego planu zagospodarowania przestrzennego, którego autorzy wskazuja, iż odesłanie w art. 37o ust. 8 u.p.z.p. do odpowiedniego stosowania do studium metropolitalnego przepisu art. 20 tej ustawy oznacza, że „rada gminy uchwala plan miejscowy dopiero po stwierdzeniu, że nie narusza on ustaleń studium metropolitalnego" (tak K. Borówka, J. Szlachetko, op. cit., s. 34).

${ }_{65}$ Zob. regulację art. 15 ust. 1 u.p.z.p., zgodnie z którą projekt miejscowego planu zagospodarowania przestrzennego sporządza się zgodnie z zapisami studium uwarunkowań i kierunków zagospodarowania przestrzennego gminy.

${ }^{66} \mathrm{~W}$ doktrynie przedmiotu podnosi się, że jedną z podstawowych zasad wyrażonych $\mathrm{w}$ przepisach u.p.z.p. jest wewnętrznie spójny system aktów planowania przestrzennego, przy czym zapewnienie spójności tego systemu wymaga ograniczenia samodzielności podmiotów uczestniczących w procedurach planistycznych, w szczególności na szczeblu lokalnym (zob. M. Szewczyk, w: Z. Leoński, M. Szewczyk, M. Kruś, op. cit., s. 52 i n.). 
administracyjnych - miejscowym planie zagospodarowania przestrzennego sposób zabudowy i zagospodarowania konkretnej działki może zostać przesądzony w studium uwarunkowań (niebędącym aktem prawa miejscowego) i kierunków zagospodarowania przestrzennego związku metropolitalnego, co uzasadnia zaliczenie studium metropolitalnego do źródeł prawa rozumianych jako akty stanowienia prawa, a dokładniej - źródła prawa sensu largo.

dr hab. Katarzyna Matysa-Sulińska

Uniwersytet Jagielloński

k.malysa-sulinska@uj.edu.pl

\author{
A FRAMEWORK OF THE FEASIBILITY STUDY \\ REGARDING SPATIAL DEVELOPMENT OF A METROPOLIS \\ AND A PLANNING CAPACITY OF A GMINA
}

Sum mary

On 1 January 2016 a new spatial development category was introduced to the Polish normative system. It is termed a framework of the feasibility study regarding urban development of a metropolitan association. Six months later, on 1 July 2017, an association the Metropolitan Association of Upper Silesia was established. In this article an attempt was made to analyse the normative character of the metropolitan feasibility study (made at the level of spatial planning for the territory of a metropolis) having in mind, in particular, its impact on gmina's spatial planning competences. 
